\title{
PROBLEME DESCHISE DE FENOMENOLOGIA LUI HUSSERL PRIN PRISMA INTEGRĂRII SALE ÎN MODELUL ONTOLOGIC INFORMAŢIONAL PROPUS DE MIHAI DRĂGĂNESCU
}

\section{PROBLEMS STARTED BY HUSSERL'S PHENOMENOLOGY IN TERMS OF ITS INTEGRATION INTO ONTOLOGICAL INFORMATIONAL MODEL PROPOSED BY MIHAI DRĂGĂNESCU}

\author{
Gorun MANOLESCU \\ Institutul de Inteligenţă Artificială "Mihai Drăgănescu”, Academia Română / \\ Research Institute for Artificial Intelligence "Mihai Drăgănescu", Romanian \\ Academy (ICIA) \\ e-mail: gmnoema@yahoo.com
}

\begin{abstract}
May another reality exist so as to generate our physical world? Both Mihai Drăgănescu and Edmund Husserl said yes. But there is a main difference between those two approaches. So, Romanian scholar Mihai Drăgănescu proposed an ontological model with strong phenomenological character in which information and material principles are at the same level. Instead Husserl proposed an idealist (transcendental) solution. In this respect Drăgănescu's model seems to be more general and consistent. Also Mihai Drăgănescu says that Husserl's Phenomenology can be integrated in his model. But for this some problems appeared. Our present work is dedicated to identifying such problems. In subsequent material we will analyze how these problems can be solved by Mihai Drăgănescu.
\end{abstract}

Keywords: lived experience; intentionality; noema; consciousness; constitution; reelle; realität; wirklichkeit;

\section{(i) Introducere}

Mihai Drăgănescu a fost preşedintele Academiei Române (1990-1994). Tot dânsul a înfiinţat, în 1992, Secţia IT a acestei Academii şi a condus-o până în 2010 când a plecat dintre noi.

Dedicate Modelului Ontologic Informaţional pe care Mihai Drăgănescu 1-a propus, şi care are la bază, ca principiu, informaţia, la egalitate cu cel al materiei, am publicat o serie de lucrări (Manolescu, 2014, 2015, 2017).

Constantin Noica (Surdu1995: 190) afirmă: „Despre Modelul drăgănescian, autorul său poate rosti, ca filosof întemeiat pe științe, această 
admirabilă vorbă, pe care numai un Hegel cuteza să o spună despre sistemul său, din perspectiva speculației «Toate filosofiile au o rațiune în lumina acestui model»” . Numai că această „,raţiune” trebuie să le integreze, adică să le adapteze pentru a le integra fără a le contrazice în spiritul lor. Iar printre aceste filozofii se regăseşte cea aristotelică, cea kantiană şi nu mai puţin important, Fenomenologia husserliană. Şi aceasta deoarece demersul drăgănescian are, de asemenea, şi o puternică tentă fenomenologică.

Textul de faţă se referă la această fenomenologie deoarece ea ridică o serie de probleme pentru care Mihai Drăgănescu a trebuit să găsească soluţii. Interesant este că, în timp ce lui Aristotel şi Kant autorul le dedică un număr important de pagini, în schimb când este vorba de Husserl el se limitează doar la câteva paragrafe din glosarul de termeni anexat uneia dintre cărţile sale fundamentale, Ortofizica (Drăgănescu, 1985).

În cadrul unei convorbiri particulare, din toamna anului 2018, cu Doamna Nora Rebreanu, soţia Profesorului, am aflat că, de fapt, cunoaşterii şi aprofundării lui Husserl, lui Mihai Drăgănescu i-a fost necesar un interval de timp considerabil. Iar rezultatele se vor vedea. Nu în acest text care are ca obiect identificarea problemelor puse în faţa Profesorului de către Fenomenologia husserliană, ci într-un material ulterior în care Mihai Drăgănescu încearcă să le rezolve.

Potrivit scopului urmărit, acest text nu va fi un studiu sau o exegeză a demersului husserlian în ansamblu, ci va încerca o distanţare selectivă faţă de concepţia acestuia, fără ca ea să fie deformată. Prin urmare, o serie de aspecte ale abordării husserliene, cum ar fi: dificultăţile observării de sine, posibilitatea unei descrieri (eidetice) a trăirilor, reflecţia şi reducţia fenomenologică ca metode, empatia şi intersubiectivitatea, logica transcendentală husserliană şi gramatica formelor pure, timpul subiectiv, ş.a.m.d., nu au fost avute în vedere.

Se cuvine ca autorul să-şi exprime gratitudinea faţă de A. Bruzan (cadru asociat la Université De Rouen unde predă cursuri de introducere în fenomenologie, fiind doctorand sub îndrumarea lui Natalie Depraz, cunoscută specialistă în Husserl, traducătoare din Fink) care a avut amabilitatea să parcurgă o primă versiune a lucrării noastre şi să ne ofere o serie de sugestii extrem de pertinente în legătură cu păstrarea spiritului husserlian.

Având însă în vedere chiar afirmaţia lui Husserl că datorită „unei fenomenologii aflată încă la începuturi, este posibil ca termenii şi conceptele propuse să prezinte o fluiditate" (Husserl, 2011: 314), am fost obligaţi ca, în anumite situaţii, să încercăm o precizare a lor ţinând seama chiar de sugestiile existente în textele autorului. Dar, în acord cu scopurile textului de faţă, a fost imposibil să nu emitem şi unele interpretări, care s-ar putea să pară neortodoxe pentru un husserlian pur. În astfel de cazuri, conform uneia dintre conotaţiile „deconstrucţiei” lui Derrida, chiar „interpretarea unui text este 
doar un alt text care nu este el însuşi o interpretare privilegiată şi care deci, la rândul său, se cere a fi interpretat" (Graham, 2002: §14.7).

\section{(ii) Premize şi definiții de bază ale abordării husserliene}

Husserl arată (Husserl, 2011: 206-207):

,[...] trebuie să înţelegem că trăirii empirice i se opune, drept condiţie a sensului ei, trăirea absolută a Fiinţei absolute şi că aceasta din urmă nu este o simplă construcție metafizică [s.n. G.M], ci ea poate fi atestată în caracterul ei absolut fără nici o urmă de îndoială prin intermediul unei schimbări corespunzătoare de atitudine, putând astfel să fie dată în cadrul unei intuiții directe" [s.n. G.M].

În acest sens, pentru a ajunge la primatul Fiinţei, complementară Conştiinţei pure (absolute), Husserl procedează în felul următor.

În primul rând, el pleacă de la un platonism reformulat. Astfel introduce o delimitare între idee şi esenţă.

„La o [delimitare] terminologică în acest sens mă împinge [...] nevoia de a păstra extrem de importantul concept kantian de idee, în aşa fel încât să fie distins în chip limpede de conceptul general de esență [...]. Voi folosi de aceea [pentru esenţă G. M.] neologismul eidos" (36).

Dar la ce „concept kantian de idee” se referă Husserl? La faptul că ideile - printre altele şi cea de Divinitate sau de Absolut - sunt, după Kant, noţiuni cu care operează raţiunea, şi a căror semnificaţie nu poate fi dată în nici o intuiţie şi experienţă posibile (Kant, 1969: 652). Iar dacă totuşi căutăm să obţinem o cunoaştere a unor asemenea entităţi, nu ne alegem, din punctul de vedere kantian (a se vedea logica sa transcendentală), decât cu paralogisme sau cădem în antinomii (307-461). În schimb, spune Husserl, esenţa (eidos) poate fi obiect de cunoaştere, prin intuiţie directă (Husserl, 2011: §5).

Particularizând, se va putea spune că Absolutul în chip de idee nu poate fi cunoscut. În schimb, ca esenţă a creativităţii sale care se va concretiza în doctrina constituirii, de care vom vorbi la timpul potrivit, el poate fi intuit direct ca Fiinţă absolută/ Conştiinţă pură.

Prin urmare, ne mai având, în continuare, nevoie de Absolut sau Divinitate, Husserl le va scoate din joc aplicând o reducţie fenomenologică (§3), metodă husserliană cunoscută, de punere între paranteze a unui anumit lucru, fără a-i nega existenţa. În acest fel Husserl rămâne faţă în faţă doar cu Fiinţa absolută.

Mai departe, Husserl introduce un alt postulat referitor la ceea ce va numi „realitate”. Şi anume, va structura această realitate pe două niveluri: (i) 
Transcendentalul şi (ii) Naturalul, ambele fiind reale. Reale în sensul că sunt accesibile cunoaşterii umane, însă diferite ca modalităţi de accesare.

Transcendentalul este un topos al lui „nici unde” şi „nici când”, deoarece Husserl nu specifică nimic în legătură cu spaţialitatea şi temporalitatea acestuia şi nici dacă este sau nu „material”.

În Transcendental se află Fiinţa absolută şi/ sau ceea ce Husserl va numi, în general, „Conştiinţă”.

Transcendentalul, conţinutul acestuia, este accesibil cunoaşterii umane prin intuiţie directă.

Realitatea sa va fi desemnată prin reelle (Husserl, 2012. Cercetarea a cincea, $\$ 2,219$ de exemplu), termen pe care îl vom utiliza şi noi, cu semnificaţia de aici.

Naturalul (Fizicul) este un alt topos în care lucrurile conţinute au întindere spaţială în trei dimensiuni şi durată temporală, iar aceste lucruri sunt de natură materială.

Conţinutul Naturalului este condiţionat de Transcendental prin Fiinţa absolută sau Conştiinţă.

Conţinutul Naturalului este accesibil cunoaşterii umane prin intermediul unei percepţii empirice care nu se reduce doar la una externă, prin cele cinci simţuri, ci va funcţiona şi intern vizând apercepţii (corporalitate şi trăiri primare cum le numeşte Husserl (Husserl 211: 317), amintiri ale unor percepţii, gânduri, judecăţi (Locke 1961: 82), etc.).

Realitatea Naturalului va fi desemnată de Husserl prin realität termen pe care, de asemenea, îl vom utiliza şi noi, cu această semnificaţie (citat de Bauman 1998: 87).

În fine, plecând de la faptul că atât în realität cât şi în reelle pot apărea lucruri iluzorii, discursul husserlian va face distincţiile: a fi real în act Wirklichkeit, a fi real potenţial - Quasi-Wirklichkeit şi a nu fi real, deci iluzoriu - Non-Wirklichkeit" (Husserl, 1994b: §2) . În aceste cazuri şi noi ne vom folosi husserlienele wirklichkeit, quasi-wirklichkeit şi non-wirklichkeit.

Cuvintele: realität, reelle, wirklichkeit, quasi-wirklichkeit şi nonwirklichkeit sunt cuvinte-cheie şi va trebui să fie ţinute minte deoarece vor fi curent utilizate în expunerea noastră.

Mai trebuie adăugat că Husserl denumeşte ,obiect”, într-un sens foarte larg, tot ce se află în Transcendental şi Natural. Astfel se va înţelege sub această denumire chiar şi ceva de gen ,justiţie”, „figura 2", „,cerc” ca figură geometrică, ,principiul terţului exclus" sau, pur şi simplu, „o stare de fapt" cum ar fi „stiloul se află pe birou împreună cu nişte cărţi”, inclusiv întreaga realität sau reelle.

De asemenea, Husserl va denumi ,fenomen" modul în care ne apare nouă un obiect, manifestarea „obiectului însuşi în carne şi oase”, dar nu şi a lucrului-în-sine kantian. Astfel ,fenomenul, este atunci totalitatea a ceea ce se 
află în plină lumină a zilei sau care poate fi adus la lumină, fiind scos din ascundere" (Heidegger, 2003: \&7,38); însă a fi adus la lumină poate însemna, pentru Husserl, şi a aplica reducţii fenomenologice succesive până la esenţa unui obiect, aceasta devenind ,ascunderea" cea mai profundă.

Comentariul 1: Aici apare prima problemă. Şi anume că în legătură cu Transcendentalul Husserl nu ne spune nimic despre toposul în care se află. Dar nu acelaşi lucru îl face orice doctrină idealistă? De exemplu, cea a lui Platon când se referă la „Lumea ideilor? Da, dar Platon e consecvent: el nu ne spune nimic în acest sens nici când se referă la „Peşteră”. În schimb Husserl nu dă dovadă de o asemenea consecvenţă în legătură cu Naturalul şi de aceea se spune că el se înscrie pe linia unui idealism parţial, i.e. unul „transcendental”. Discuţia aici se poate prelungi indefinit odată ce, în filozofie a fost admis idealismul. Asta nu înseamnă că problema idealismului, în general şi a celui particular la Husserl, nu există.

Comentariul 2: A doua problemă. Modul în care Husserl vede „,realitatea" nu înseamnă nimic altceva decât introducerea, pe uşa din dos, a metafizicului, adică a acelui „ceva” din afara omului; plecând de la premiza că acest ceva, chiar şi redus la „Fiinţa absolută” poate fi perceput de om printr-o , intuiţie directă".

\section{(iii) Conştiinţa în genere, trăire şi act.}

Conform lui Husserl, ,conştiinţa” în sensul cel mai larg posibil, poate fi considerată drept totalitatea reală (reelle) a „trăirilor” fiinţei umane şi interţeserea acestor trăiri de orice fel în unitatea fluxului lor (Husserl, 2012: 218). Ea se află în Transcendental şi este similară, dar nu identică cu cea a altor animale. Ceea ce diferenţiază o conştiinţă de tip uman de una a altor animale este că ea poate fi auto-percepută prin reflecţie, aceasta devenind una dintre caracteristicele principale ale acestui fel de conştiinţă.

Dar ce ar putea să însemne o „trăire” şi, separat, un ,act” de conştiinţă?

O trăire, după Husserl, este ceva ce se oferă ea însăşi percepţiei, cu o evidenţă de necontestat (esse est percipi) (Dermot, 2012), pe când, în schimb, referindu-se la actele de conştiinţă Husserl foloseşte termenul «Erlebnis» [trăire] (Dermot, 2012) pentru a semnifica starea de conştiinţă drept o trăire personală ca o experienţă a persoanei a treia. Astfel credem că putem înlătura acum această neclaritate.

Prima dată, fenomenologul, pe post de persoana întâi, experimentează conţinutul conştiinţei ca fiind alcătuit din propriile trăiri; dar simultan, ca persoană a treia, experimentează conţinutul conştiinţei ca fiind alcătuit din trăiri pe care nu le-a produs el (persoana a treia) ci persoana întâi şi pe care le 


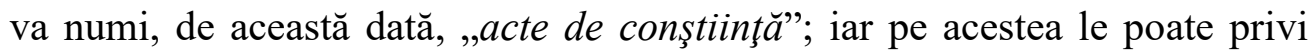
detaşat, le poate descrie şi analiza.

Comentariul 3. Putem acum să facem observaţia că această duplicitate apare pentru că una şi aceiaşi „,realitate” este văzută şi numită diferit în funcţie de punctul de vedere al observatorului, ceea ce reprezintă un fel de „complementaritate” avant la letter. Iar o astfel de complementaritate introdusă implicit de Husserl va constitui una dintre caracteristicile „reducţiei fenomenologice” ca metodă. Ceea ce, după câte cunoaştem, nu a fost până acum pus în evidenţă.

Cam atât, deocamdată, despre trăiri şi acte de conştiinţă asupra cărora vom reveni. De asemenea, menţionăm că Husserl utilizează şi alte nuanţe ale noţiunii de ,act de conştiinţă" şi, în acest sens, se pot consulta cele două dicţionare aparţinând lui Drummond (2007) şi, respectiv, Dermot (2012).

\section{(iv) Ontologie formală şi ontologie materială}

În paragraful al doilea al acestui text $\mathrm{s}$-a redus fenomenologic Absolutul şi am rămas faţă în faţă cu Fiinţă absolută. A fost o reducţie de sus în jos (top down). De fapt Husserl a plecat şi invers, de jos în sus (bottom up) pentru a pune mai clar în evidenţă aceiaşi Fiinţă absolută. Şi anume a plecat de la punerea între paranteze a modului în care ştiinţele numite de el „eidetice pure" - logica şi matematica - privesc lucrurile şi apoi a trecut la scoaterea din joc şi a aşa numitei ,atitudini naturale” proprie ştiinţelor naturii.

În continuare discursul nostru va lua în considerare două noţiuni husserliene, ontologia formală proprie logicii şi matematicii ambele pure şi ontologie materială proprie ştiinţelor naturii.

Ontologia formală este introdusă de Husserl în filozofie drept o descriere a unor obiecte de tip „formă” (Henning, 2006). În afară de sensul care atribuie „esenţei” denumirea de „eidos”, Husserl mai utilizează şi altă semnificaţie a acestuia şi anume de ,formă esenţială” (fără materie) (Husserl, 2011: §10). Prin urmare, aici este vorba de o distincţie între formă şi materie.

Astfel, când vorbim despre „formal”, înţelegem că, în acest caz, percepţiile şi judecăţile au ca obiect entităţi de tip „formă”.

Logica şi matematica, ca discipline, sunt într-adevăr formale când „formele vide”, cum spune Husserl, nu sunt „umplute” cu materie. Acest mod de a vedea lucrurile aminteşte de intuiţionismul matematic, considerat a fi de natura unui platonism în care ideile, ca existenţă, sunt înlocuite cu obiectele matematicii.

Comentariul 4: Despre modul de exprimare, în acest caz, se poate spune precum Heyting: „Limbajul în care matematica se exprimă, fie acela 
obişnuit, fie acela formalizat, nu serveşte decât la comunicarea rezultatelor şi oferă numai o imagine - bild - a matematicii, dar matematica nu este această imagine şi cu atât mai puţin limbajul în care o exprimăm" (Heyting, 1934, citat de Dumitriu, 1969: 797).

Mai trebuie spus că în cadrul ontologiei formale, procesul mental care are ca obiect ,adevărul” se bazează pe de o parte, pe o gândire conceptuală care se desfăşoară deductiv, plecând de la genul maxim (categorie) şi avansând, prin descompuneri, pe niveluri succesive de detaliere, până la anumite elemente terminale (obiecte nedecompozabile) şi, pe de alta, pe cele trei principii logice formale şi ideale: identitate, necontradicţie şi terţ exclus. În acest fel, la nivelul genului maxim se află premizele, ca axiome reprezentând adevărul existenţial reelle apodictic, cel mai general. Iar odată $\mathrm{cu}$ detalierea pe diverse niveluri, prin emiterea de consecinţe care nu contrazic axiomele, adevărul axiomelor se prezervă (moşteneşte) fiindu-i adăugate noi precizări. Prin urmare, de sus până jos, adevărul nu se modifică ci doar se rafinează.

Comentariul 5: În legătură cu o ontologie formală apar două întrebări: (a) în ce fel de topos există ea? şi (b) în ce mod are omul acces la o obiectele unei asemenea ontologii? Husserl răspunde doar la a doua întrebare şi anume că accesul omului este realizat printr-o intuiţie directă ca şi în cazul obiectelor care se află în Transcendental. Aceasta ar putea să subînţeleagă faptul că şi această ontologie s-ar afla tot în Transcendental. Dar despre aceasta Husserl nu afirmă nimic. Am semnalat totuşi neclaritatea respectivă doar pentru ca ea să nu fie atribuită discursului nostru. De fapt, în demersul husserlian, ea nu impietează în mod deosebit, dar am considerat că este bine ca ea să fie menţionată.

Şi acum să trecem la ontologia materială proprie unei ,,atitudinii naturale". Această atitudine pleacă de la modul în care ştiinţele naturii privesc lucrurile atunci când formele vide capătă un conţinut material.

Ştiinţele naturii, după Husserl, sunt considerate că se ocupă de domeniul Naturalului (Fizicului) care se află în spaţio-temporalitatea cu întindere în trei dimensiuni şi durată în timp şi este susţinut „material” fiind o realitate de tip realität.

Astfel (Husserl, 1994a) spune că în interogarea ştiinţifică naturală se pleacă de la ce este dat ca obiecte din lumea noastră fizică („Este suficient să ne amintim de naivitatea [că] ştiinţa naturii acceptă natura ca dat", (18)). Prin urmare aceste obiecte nu trebuie niciodată să fie interogate ci trebuie luate ca fiind fundamentul de la care investigaţia știinţifică trebuie să plece. $\mathrm{Cu}$ alte cuvinte oamenii de ştiinţă ,naturală” consideră că lumea fizică trebuie să 
constituie propria axiomă. Pentru această raţiune Husserl arată că în măsura în care dorim să avem acces la această lume noi trebuie, conform empirismului pozitivist al interogării de sorginte ştiinţifică, să o considerăm, într-un fel, drept lucru însuşi [Sache selbst] şi nu lucrul în sine kantian.

Autorul începe critica sa a ştiinţelor naturale notând anumite absurdităţi care devin evidente când un asemenea empirism este adoptat (12).

Urmându-l pe (Cogan, 2006), care face apel la Husserl, vom spune cele ce urmează.

Ştiinţele naturale sunt ştiinţe evident empirice şi astfel ele au de-a face cu fapte empirice. Prin urmare atunci când principiile logic-formale ideale, aparţinând ontologiei formale (identitate, necontradicţie, terţ exclus), sunt subsumate legilor Naturii ca legi ale gândirii, aceasta conduce la considerarea lor ca unele dintre multele legi ale naturii. Dacă am proceda în acest fel, ar trebui să ţinem seama că modul în care o lege naturală poate fi stabilită şi justificată este, prin inducţie, din fapte singulare ale experienţei.

Inducţia însă nu stabileşte certitudinea legii ci numai o mai mare sau mai mică probabilitate a acesteia. Aceasta ar înseamnă că legile gândirii trebuie, în acest caz să posede un anumit grad de probabilitate. Contradicţia este evidentă. Absurditatea în practică devine efectivă când notăm că naturalistul este dominat de scopul de a considera cunoaşterea ştiinţifică (epistemologia) întotdeauna ca fiind în măsură să producă un adevăr autentic absolut, i.e. cel mai general, apodictic existenţial, utilizând principiile ideale amintite ale gândirii.

Mai clar, în acest caz, prin inducţie se pleacă de jos în sus, de la obiecte fizice, materiale, considerate a fi elemente terminale şi se determină ceea ce le este comun. Se constituie astfel un prim şi singur nivel sintetic al „adevărului” şi procesul se opreşte. Prin urmare, nimeni nu va putea decela adevărul general al axiomelor deoarece nu se ajunge la ele. Şi, de asemenea, nu se va putea spune dacă el există fiind „moştenit”, sau nu, în cadrul acestui prim şi ultim nivel de sinteză. În concluzie, se poate afirma fără dubii că prin inducţie nu se poate obţine decât un adevăr posibil (relativ) şi nu unul autentic ${ }^{1}$.

Să revenim la ,atitudinea naturală”.

\footnotetext{
${ }^{1}$ Lucru consemnat de explozia apărută în cadrul logicii pentru ca aceasta să poată face faţă descrierilor unor domenii specific ale realităţii materiale: apariţia, mai întâi, a logicilor polivalente (Moisil), apoi a logicilor fuzzy (Zadeh, Negoiţă) ca, în prezent, să se pună un accent deosebit pe logica modală (iniţierea acestei tendinţe aparţinând lui Lukasievici) ale cărui principii şi valori de adevăr fuseseră, de fapt, puse în evidenţă chiar de Aristotel în cap. 2 (Despre interpretare) din Organon în cadrul căruia, în contrast cu cele trei principii ale unei logici ideale puse în evidenţă în capitolul 1 al cărţii, el utilizează "terţul inclus" acceptând "posibilitatea" şi mai mult chiar, admite încă o nouă valoare de adevăr, de-a dreptul subversivă, cea a "viitorului contingent". Despre Dialetheism şi logicile paraconsistente nu mai vorbesc.
} 
Husserl caracterizează această atitudine în felul care urmează (Husserl, 2011: §27-§30).

În calitate de oameni ai vieţii naturale avem reprezentări, judecări, simţiri, voinţe într-o ,atitudine naturală”. Percepem şi devenim conştienţi, adică avem o serie de „trăiri” sau „experienţe vii”, că:

- Lumea se întinde şi se schimbă la nesfârşit în spaţiu şi timp;

- Lucrurile corporale, inclusiv fiinţe animale şi oameni, sunt, pur şi simplu, prezente;

- În raport cu aceste lucruri (obiecte) noi avem sentimente pe care, de asemenea, le percepem;

- Cele de mai sus sunt independente de o ordine pe care însă o percepem ca pe una statică la un moment dat, dar care se schimbă instantaneu, în continuu;

-O asemenea ordine pe care o sesizăm (percepem), şi o judecăm numind această judecată ,cogito”, se referă la realitatea (realität wirklichkeit) care mă înconjoară efectiv, dar ea se poate referi uneori şi la altă realitate reelle wirklichkeit cum at fi numerele pure şi legile lor, formaţiuni complexe de astfel de numere, figurile geometrice şi legile lor, principiile logice şi ceea ce numim gândire conceptuală, etc., numai că lumea realität wirklichkeit rămâne în continuu prezentă pentru mine, chiar dacă „umbrită”, iar noi continuăm să ne aflăm astfel în atitudinea naturală.

\section{(v) Prima revenire la trăiri}

Suntem acum în măsură să revenim cu detalii în privinţa „trăirilor”.

În primul rând vom observa că Husserl, atât când ce referă la o atitudine naturală cât şi la una care vizează formalul, în afara percepţiei unor obiecte externe ale celor două ontologii el merge pe ideea că tot obiecte sunt şi unele interne, supuse apercepţiei, cum ar fi cogitaţiile, sentimentele, precum şi amintirile. Prin urmare, în toate aceste cazuri, va fi vorba de un proces de perceptie a unor obiecte nu numai materiale ci şi abstracte (i.e. „cogitaţii”) sau greu de definit (i.e. sentimente). Evident că obiectele luate în considerare vor fi de tipuri diferite. În schimb conţinutul procesului de percepţie/ apercepţie va fi esenţial identic. Ori tocmai o asemenea identitate a esenţei conţinutului va conduce la apariţia unei „trăiri” („experienţe vii”), respectiv, ,act de conştiinţă".

Toate cele de mai sus vor permite, deocamdată, să partajăm actele de conştiinţă în: (i) formale şi (ii) ale atitudinii naturale. O asemenea partajare conduce la alta similară privind conţinutul unei conştiinţe, în sens cel mai general posibil.

Anticipând vom spune că în afara tipurilor de acte „formale” şi ale „atitudinii naturale”, într-o conştiinţă, în general, vor mai exista şi acte de al treilea tip: „pure”, despre care vom discuta imediat. 


\section{(vi) Punerea între paranteze a ştiinţelor eidetice pure (ontologiei formale) şi a ştiințelor naturii (ontologia materială)}

Ce mai rămâne dacă scoatem din joc (reducem fenomenologic) tot ce ţine de formal şi atitudinea naturală? Este întrebarea pe care şi-o pune Husserl. De fapt, această reducere se referă la punerea între paranteze, în cadrul conştiinţei, a trăirilor „atitudinii naturale” şi pe cele „formale”, iar Husserl va afirma că, prin această scoatere din joc va mai rămâne ceva şi anume un „rest fenomenologic”. Acest rest este „,conştiinţa pură în absoluta ei fiinţă proprie", identificabilă, în termeni husserlieni, printr-o intuiţie directă:

„De asemenea, trebuie să înţelegem că trăirii empirice i se opune, drept condiţie a sensului ei, trăirea absolută şi că aceasta din urmă nu este o simplă construcţie metafizică, ci ea poate fi atestată în caracterul ei absolut fără nici o urmă de îndoială prin intermediul unei schimbări corespunzătoare de atitudine, putând astfel să fie dată în cadrul unei intuiţii directe" (Husserl 2011: 206-207).

Iată modul în care se ajunge la ea:

„[...] în loc să efectuăm în mod naiv actele proprii conştiinţei în legătură cu natura, [şi formalul, G.M.], odată cu tezele lor transcendente [transcendente în raport cu, ,restul" fenomenologic G.M.], [...] noi „scoatem”, dimpotrivă , „din funcţiune” toate aceste teze, aşadar nu le mai dăm girul, îndreptându-ne privirea asupra conştiintei pure în absoluta ei fiinţă proprie, pentru a o sesiza şi a o cerceta în chip teoretic. Iată, prin urmare, ce anume rămâne în urmă, în calitate de „reziduu fenomenologic”, atunci când scoatem din circuit întreaga lume [inclusiv formalul G.M], odată cu toate lucrurile, vieţuitoarele şi oamenii din cuprinsul ei, inclusiv pe noi înşine (187).

Şi, mai adaugă: „De fapt, nu am pierdut nimic prin aceasta, ci, dimpotrivă am câş̧igat întreaga fiinţă absolută care, înţeleasă corect, ascunde în sine toate transcendenţele lumii, în măsura în care le «constituie» în sine".

Acest citat rezumă sugestiv doctrina constituirii care va face obiectul paragrafului următor.

Până atunci vom mai arăta că trăirile naturale şi cele formale din Transcendental, care au fost scoase din joc, vor putea reprezenta obiectul unor fenomenologii diferire de cea pură, căci:

„,...] în ciuda scoaterii din circuit a naturii fizice, există nu numai o fenomenologie a conştiinţei proprii ştiinţelor naturii [având ca obiect trăirile naturale G.M.] [...]. În mod similar, există, în ciuda faptului că 
psihologia şi ştiinţele spiritului sunt lovite la rândul lor de scoaterea din circuit, o fenomenologie a omului; [...] în fine, există o fenomenologie a spiritului social, a configuraţiilor sociale, a realizărilor culturale ş.a.m.d. În măsură în care ajunge să fie dată pentru conştiinţă [sub formă de trăire G.M.], orice transcendenţă [inclusiv una formală G.M.] face obiectul unei cercetări fenomenologice [...]" (268).

De toate aceste fenomenologii ar trebui să se ocupe continuatorii, Husserl rezervându-şi dreptul de a se focaliza asupra fenomenologiei pure; a se vedea, în acest sens, şi titlul operei sale capitale: Idei privitoare la o fenomenologie pură....

\section{(vii)Doctrina constituirii}

Să observăm, mai întâi, că respectiva Conştiinţă pură (în absoluta ei fiinţă proprie) este aprioricăa, deoarece ea este „o conştiinţă donatoare de sens, care este la rândul ei absolută şi nu există în virtutea unei noi donaţii de sens” ( $\$ 55,207)$. În schimb, ea poate ,dona sens”.

Ce reprezintă această ,donare de sens” a Conştiinţei pure? Ea reprezintă, de fapt intrarea în Existenţă. A cui? A ,tuturor (sub)regiunilor de fiinţă”, pentru că: , Prin intermediul reducţiei fenomenologice a rezultat pentru noi ţinutul conştiinţei absolute, pure, înţeles într-un sens foarte precis, ca ţinut al fiinţei ,absolute”. Aceasta reprezintă categoria originară a ființei în genere [...] în care își au rădăcinile toate celelalte (sub)regiuni de ființă [s.n. G.M.]" (§76, 267).

Comentariul 6: Celelalte (sub)regiuni de fiinţă reprezintă, de fapt, pe de o parte, ,fiinţa” Formalului şi, pe de alta, cea a Naturalului cu toate obiectele pe care acestea le conţin. Dacă ne vom referi la obiectele fizice din Natural: inanimate şi animate, important este că, de fapt, lor nu li se acordă „viaţă” cum greşit s-ar putea inţelege la o primă vedere, ci, doar, „, existenţă”, ca şi celorlalte obiecte din Formal. Iar în acest caz, daţi-ne voie să folosim termenul de ,fiinţare”, introdus ulterior de Heidegger, dar nu în sensul propus de acesta (a se vedea (Ciocan 2007)), ci, in sens de ,existenţă”.

Devine acum evident ce va însemna ,umplerea cu sens” realizată de Fiinţa pură absolută şi anume, repetăm, conferirea de existenţă pentru toate obiectele din atitudinea naturală şi din formal. Ceea ce, în ultimă instanţă, înseamnă că o parte din Transcendental, prin intermediul Fiinţei pure absolute, „constituie” Formalul şi Naturalul. Şi, de asemenea, va rezulta şi semnificaţia sintagmei husserliene şi anume că ,orice realitate [realität sau reelle G.M.] există doar prin «donaţie de sens»" (titlul §55). 


\section{(viii) A doua revenire la trăiri}

Apare acum în „conştiinţa pură absolută” un nou tip de trăiri şi anume „trăirile pure”. Şi dacă celelalte tipuri apăreau în urma unor percepţii şi apercepţii corespunzătoare obiectelor aferente atitudinii naturale şi formalului, atunci „trăirile pure” se vor datora în primul rând, unor procese perceptive de obiecte pure, adică de tipul unor „fiinţări”. Iar astfel de fiinţări vor fi, întotdeauna externe subiectului, ca şi obiectele fizice şi cele formale, şi nu mentale (interne). Prin urmare, ele sunt „obiective” fiind datorate unei „umpleri cu sens” de către Fiinţa pură absolută a obiectelor fizice naturale şi a celor formale.

În acest caz apar cel puţin două întrebări: (i) ce diferenţă este între perceperea proprietăţilor (atributelor) unui obiect fizic sau formal şi perceperea unei „fiinţări”? şi, (ii) cum este posibilă perceperea unei „fiinţări”?

La prima întrebare vom încerca să răspundem imediat. La a doua, în paragraful imediat următor.

Pentru prima întrebare vom apela la răspunsul dat de Schmitz, răspuns care sintetizează extrem de clar diversele susţineri aparţinând lui Husserl, în diferite contexte.

„O existenţă nu este un atribut a ceva, adică nu este ceva esenţial pentru identitatea unui lucru, ceva care să contribuie direct la determinarea unui lucru, drept acest lucru. Fiecărui lucru îi aparţin în mod necesar atribuitele sale, căci un lucru este în mod esenţial identic cu sine, acest lucru şi nu un altul. Niciun lucru nu poate fi determinat de alte atribuite decât de cele care îi revin, de facto, lui însuşi. Dacă existenţa ar fi atributul unui lucru, acesta ar trebui, prin urmare, să existe. Se poate arăta însă cu uşurință că nimic nu există cu necesitate. [...] De aici rezultă că existenţa nu este un atribut şi că nici o inducţie a existenţei [Existenz-Inductivum] nu poate fi considerată un atribut" (Schmitz forthcoming: 39-40).

Prin urmare, o trăire este o percepţie de cu totul altă natură decât cea a uneia prin care se poate stabili, cu ajutorul unor atribute, identitatea unică a unui obiect realität sau reelle, indiferent dacă el ni se prezintă direct (,în carne şi oase”) sau indirect, printr-un „semn” sau o „imagine” (Zahavi, 2017: 49) . Semnificaţia perceperii unei trăiri este că ea reprezintă perceperea unei „unităţi de sens” asociată, în acest caz, unui obiect realität/ reelle de către Conştiinţa pură (§55). De aici rezultă că o asemenea unitate de sens poate să existe în act (wirklichkeit) sau potenţial (quasi-wirklichkeit), deci nu iluzoriu (non-wirklichkeit). Despre aceste posibilităţi de existenţă ale unei unităţi de sens vom discuta în paragraful următor. 
Până atunci, vom observa, numai în treacăt, deoarece nu vom dezvolta acest subiect, că o trăire care a provenit din percepere unei alte trăiri nu poate avea întotdeauna drept obiect numai o singură altă trăire. Aici este vorba de „reflecţie” drept o a doua metodă a fenomenologiei husserliene, prima fiind „reducţia fenomenologică”. Astfel, ne spune Husserl că, prin reflecţie, putem avea o trăire asupra, de exemplu, a obiectului „conştiinţă pură individuală”, iar, mai departe, dacă reflectăm asupra convingerii pe care o trăim că există conştiinţă pură individuală, vom avea de-a face, în cazul reflecţiei, cu două trăiri cuprinse una în alta (143).

Comentariul 7: Pot exista oare şi lanţuri de ,incluziuni”, cum le numeşte Husserl, care să cuprindă trăiri multiple în cazul cărora fiecare trăire superioară nu este autonomă ci fondată pe cea inferioară, până la infinit? Husserl nu ne spune nimic despre aceasta. In schimb, iată cum Wigner, laureat Nobel pentru fizică, tratează un asemenea caz, evitând regresia la infinit prin ajungerea la ceea ce Husserl numeşte „Conştiinţa pură absolută". In cele ce urmează ne vom permite să înlocuim celebra „pisică a lui Schrödinger" cu perceperea pură a existenţei (fiinţării), sau nu, a unui obiect fizic sau formal (Kaku, 2016: 549-595).

În cazul perceperii (sau nu) a unei fiinţări asociate unui obiect din Natural sau Formal, nu vom putea şti dacă ea există sau nu decât în momentul în care se încearcă, de către un eu individual pur, realizarea unei asemenea perceptii. Deci este imposibil de a separa observatorul de obiectul observat. Şi în această situaţie observatorul [eu-ul pur individual G.M.] poate, la un moment dat să existe sau nu. Cine îl observă? Există o funcţie de undă (Schrödinger) care include atât observatorul cât şi obiectul. Ca să ne asigurăm că observatorul există, e nevoie de alt observator (,,prietenul lui Wigner") care să colapseze unda pentru a determina viabilitatea primului observator. Dar de unde ştim că al doilea observator este viu [fiinţează G.M.]? Este acum nevoie de un al treilea observator ş.a.m.d. Intrucât este nevoie de un număr infinit de observatori ca, prin colapsarea succesivă de unde, să fim siguri că ei există, avem nevoie de o „,conştiinţă cosmică”. Şi Wigner conchide: „Nu a fost posibil să formulăm legile (teoriei cuantice) intr-o manieră pe deplin coerentă fără să facem apel la conştiinţă".

In acest mod, "Eu-ul" se extinde identificându-se cu o astfel de conştiinţă.

\section{(ix) Intenţionalitatea}

Prin ,intenţionalitate” se concretizează pe deplin creativitatea Fiinţei absolute care a început cu ,constituirea”. Aceasta înseamnă că, în timp ce constituirea acorda „fiinţare”, i.e. existenţă, oricărui obiect natural (fizic) sau formal, în schimb intenţionalitatea permite perceperea acestei fiinţări. 
Textele husserliene fac nenumărate referiri la ,intenţionalitate”, mai ales asupra înţelesului pe care i l-a acordat Brentano şi a modului în care ea a fost reinterpretată de către Husserl. Pe noi nu ne va interesa diacronia respectivă a intenţionalităţii ci numai semnificaţia pe care Husserl i-a atributo.

Husserl consideră că a fi conştient, înseamnă a fi conştient de ceva. Aceasta înseamnă o orientare asupra acestui ,ceva" care poate fi un obiect natural sau formal sau chiar din Conştiinţă, i.e. o trăire.

In sensul celor de mai sus, rezultă că însăşi această orientare, pe care Husserl o consideră a fi intenţionalitatea, este, ca şi reflecţia, o proprietate a Conştiinţei.

Concretizând, orice act al conştiinţei: percepţie, judecată/ raţionament, îndoială, aşteptare, amintire sau fantezie se caracterizează prin faptul că intenţionează un obiect de un anumit tip. Şi, de asemenea, mai rezultă că o intenţie nu încetează de a fi ,,intenţională” indiferent dacă obiectul există sau nu. Iar o asemenea intenţie face posibilă perceperea „fiinţării” obiectului sau, dacă aceasta nu există, fiind vorba de o iluzie, apare tendinţa subiectului de ai acorda el însuşi fiinţare, tendinţă moştenită de la Fiinţa absolută.

Dacă în privinţa perceperii fiinţării, atunci când ea există, lucrurile sunt clare, în legătură cu tendinţa de acordare de fiinţare de către subiect atunci când ea lipseşte nu mai este aşa. Pentru explicaţii va fí nevoie de o paranteză. Ea se va referi în special la jocul noematic pentru ,surprinderea" (aprehendarea) unui obiect natural sau formal. Mai bine zis, nu atât la procesul în sine, i.e. la „noesis”, cât la rezultatul acestuia, i.e. „noema”. În diverse texte husserliene termenul „noema” apare cu înţelesuri diferite. Astfel, aşa cum arată Dermot (Dermot, 2012: Noema):

„Noema înseamnă obiectul intenţional aşa cum e perceput, aşa cum e judecat, aşa cum e dorit, în general: aşa cum e intenţionat. În (Husserl, 2011: §95) el susţine că doctrina noemei este „de cea mai mare importanţă pentru fenomenologie". În altă parte el spune că luarea în considerare obiectul intenţional ca noemă aceasta este un ,clu transcendental" pentru întreaga multiplicitate a experienţelor posibile sau cogitaţii (Husserl, 1994: §26). Analiza lui Husserl în ceea ce priveşte noesis şi noema este extrem de importantă pentru înţelegerea fenomenologiei sub reducţia fenomenologică. Noema este un element cheie în descrierea eidetică a conştiinţei ; ea este o „obiectivitate aparţinând conştiinţei într-un mod specific" (Husserl, 2011: §128). Noema este întotdeauna corelată cu un act noetic sau „,noesis”; ea este obiectul aşa cum este perceput, gândit, imaginat. În noema Husserl înglobează într-o singură entitate complexă ceea ce Frege include sub termenul de ,sens" mod de prezentare, şi funcţie referenţială a actului, i.e. obiectul intenţional al actului. Husserl scrie: ,noema în ea însăşi 
are o relaţie obiectivă, mai particular în virtutea propriului sens" (§128) ş.a.m.d.

Şi, mai departe, tot Dermot adaugă:

,[...] Înţelesul exact şi statutul noemei la Husserl este controversat. El a dat loc unor multiple discuţii în legătură cu natura unei teorii fenomenologice a înţelesului şi naturii unui obiect intenţional. În acord cu o interpretare standard, propusă original de Gurwitsch, noemata sunt entităţi ideale - literar sensuri ideale abstracte - care permit unui act intenţional să se refere la obiectul său intenţional. Alţii, e.g. John Drummond şi Robert Sokolowski, argumentează că noema este pur şi simplu obiectul intenţionat. Conform acestei interpretări, noema este un termen tehnic pentru a se referi cineva la obiectul intenţionat ca o tematizare explicită în reducţia fenomenologică” (Dermot, 2012).

Însă tor Husserl afirmă la un moment dat că: ,,pomul real poate fi ars, distrus, dar niciodată noema 'copac' " (§89).

Comentariul 8. Dacă vom lua în considerare această afirmatie a lui Husserl şi o vom corobora cu alta care, de asemenea, îi aparţine, că ceea ce numim Conştiinţă pură absolută care, la rândul său, poate genera atât conştiinţe individuale cât şi obiectele lume naturală (în ansamblu) şi lume formală (tot în ansamblu) nu ,, ar fi nicidecum atinsă în existenţa sa proprie”, dacă ar fi anihilate cele două lumi (\$49,183], atunci am putea avansa ipoteza că o fiinţare poate fi asociată oricărui obiect din cele două lumi în două feluri: în act, adică în mod realität/ reelle, wirklichkeit sau numai potenţial, quai- wirklichkeit, urmând ca apoi să poată deveni oricând wirklichkeit, i.e. ne-iluzoriu.

Această ipotezăa, în spiritul gândirii husserliene, ne oferă prilejul să afirmăm că, în cadrul ,constituirii” celor două lumi, Conştiinţa pură absolută $\hat{\imath} s ̧ i$ ia Omul drept partener al creativităţii sale în sensul că atunci când intenţionalitatea vizează un obiect potenţial se va realiza o percepţie a „fiinţării" sale ca şi în cazul în care acesta ar exista în act (de facto). Nu acelaşi lucru se va întâmpla însă în cazul în care avem de-a face cu ceva iluzoriu.

\section{(x) O incongruență şi un paradox}

Husserl ne spune:

„Prin intermediul reducţie fenomenologice a rezultat pentru noi ţinutul conştiinţei pure, înţeles într-un sens foarte precis, ca ţinut al fỉinţei 
,absolute”. Aceasta reprezintă categoria originară a fiinţei în genere [...] în care îşi au rădăcinile toate celelalte regiuni de fiinţă; ele se raportează toate, prin însăşi esenţa lor, la ea şi depind astfel în chip esenţial de ea. Teoria categoriilor trebuie neapărat să pornească de la această diferenţă de fiinţă - cea mai radicală dintre toate - dintre fiinţa inţeleasă drept conştiinţăa, pe de o parte, şi fiinţa inţeleasă drept „,transcendenţă”, ce se „relevă” în conştiinţăa, pe de altă parte” (267).

Dacă lucrurile stau aşa, atunci apare „monadologia” lui Husserl. În sensul că fiecare conştiinţă individuală constituie o instanţă (subcategorie) de fiinţă. În cadrul „monadologiei” sale Husserl adoptă acest termen, precum şi pe cel de „monadă”, în special în scrierile sale târzii. „Monada” şi „monadologia” sunt termeni preluaţi de la Leibnitz cărora Husserl le acordă altă semnificaţie, mai ales în Meditaţii Carteziene (Husserl, 1994b: § 37).

Acum apare acea ,incongruenţă” din titlu. Şi anume că, pe de o parte, fiinţa (absolută) este inţeleasă drept conştiinţă (pură, absolută), dar, din paragraful al treilea al acestui text putem deduce că într-un sens general, dar nu cel mai larg posibil, ,' 'conştiinţa' poate fi considerată şi drept totalitatea reală (reelle) a 'trăirilor pure' umane şi inter-ţeserea acestor trăiri de orice fel în unitatea fluxului lor" (Husserl, 2012: 218). Deci se poate presupune că, în cadrul conştiinţei pure absolute, din care derivă toate conştiinţele individuale pure, ar trebui să se găsească, sub o anumită formă, această ,totalitate a trăirilor umane pure”, inclusiv ,inter-ţeserea lor”. Însă despre aceasta Husserl nu spune nimic. Incongruenţa ar putea să dispară dacă vom considera că în „,conştiinţa pură absolută" se află potenţial ,, totalitatea trăirilor pure umane” şi etc., iar ele intră în act, ca părţi ale acestei totalităţi, în cadrul fiecărei conştiinţe individuale.

Să ne referim acum la paradoxul menţionat în titlu. Lyotard propune o altă interpretare a „,constituirii” şi ,intenţionalităţii” decât cea prezentată de noi în paragrafele vii şi ix. Astfel, el constată un lucru extrem de interesant. Raţionamentul său pleacă de la faptul că eu-ul pur individual este parte a euului pur absolut, obiectiv, respectiv al Conştiinţei pure absolute. Prin urmare şi el capătă astfel un caracter ,obiectiv”, pentru că va participa la o „,constituire” deşi individuală (subiectivă) a lumii fizice în ansamblu, în calitate de ,obiect” [realität G.M.]. Evident, „subiectivitatea obiectivă” a ego-ului pur individual va reprezenta, pentru Lyotard, şi nu numai, un paradox. Iată citatul din Lyotard:

,în realitate, subiectul perceptiv este acelaşi care constituie lumea, în care se afla, în acelaşi timp, prin percepţie. Când îl explorăm din perspectiva împletirii sale cu lumea, pentru a-l deosebi de aceasta lume, folosim criteriul de imanenţă; dar situaţia paradoxala provine din faptul ca însuşi conţinutul acestei imanenţe nu este altceva decât 
lumea ca ţintă, ca fenomen, cu toate ca aceasta lume este instituită ca existenţă reală şi transcendentă prin eu”. (Lyotard, 1954: 27).

Comentariul 9. Dacă luăm în considerare comentariul precedent (8), atunci paradoxul dispare. Astfel: (a) dacă lumea care îl auto-conţine (pe om) a fost constituită ,,in act" (de Conştiinţă pură), atunci el o va percepe şi nu o va „constitui”; (b) dacă lumea care îl auto-conţine a fost constituită „potential", atunci el, omul, o va „pune in act” (o va constitui şi o va şi percepe) drept o lume paralelă sau intersectată cu cea existentă anterior - şi aici apare creativitatea (controlată) a omului pe care i-o conferă Conştiinţa pură; (c) dacă lumea care îl auto-conţine nu a fost constituită nici „potenţial” şi nici , în act”, atunci omul va crea numai ceva iluzoriu.

\section{(xi) O nouă perspectivă: ,apofatic-catafaticul”}

O asemenea perspectivă asupra fenomenologiei lui Husserl, este extrem de utilă pentru a vedea ce se întâmplă atunci când această fenomenologie este pusă faţă în faţă cu modelul ontologic informaţional aparţinând lui Mihai Drăgănescu (Drăgănescu 1979, 1985, 2007). Este vorba de a privi lucrurile prin prisma a ceea ce se numeşte abordarea ,apofatic-catafatică”.

Dar ce înseamnă această abordare? În acest paragraf o vom prezenta pe scurt.

Trebuie făcută o distincţie netă între ,apofanticul” aristotelic (greceşte:

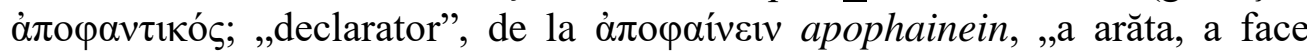
cunoscut”) şi ,apofaticul” cunoaşterii.

Apofaticul şi Catafaticul reprezintă două posibilităţi limită ale cunoaşterii umane înainte ca aceasta să întâlnească definitiv Divinitatea/ Absolutul despre care nu se mai poate spune chiar nimic (Manolescu, 2018).

Conform doctrinei „Apofatic-Catafatice”, există o punere în evidenţă afirmativă (catafatică) a modului în care Absolutul (Divinitatea/ Dumnezeu) se manifestă la vedere în lumea noastră de toate zilele şi o punere în evidenţă negativă (apofatică), ascunsă, în care acţiunea acestui Absolut nu poate fi pusă în evidenţă în modul discursiv obişnuit.

Accesul uman la cele două modalităţi limită de cunoaştere se realizează printr-o intuiţie directă ca şi cea propusă de Husserl.

Deşi denumirea de „Apofatic-Catafatic” a apărut în dogmatica creştină din Evul Mediu, rădăcinile celor două modalităţi de cunoaştere se regăsesc în gândirea antică. Le putem identifica chiar la presocratici.

Vorbind de Apofatic, evident fără să-1 numească astfel, Heraclit, spune: „Oamenii [obişnuiţi] se arată neputincioşi să pătrundă sensul cestui logos care există dintotdeauna” (Piatkovski \& Banu, 1979: 350); sau „Cercetând hotarele sufletului/ [ființei], n-ai putea să le găseşti, oricare ar fi cărarea pe care vei merge. Atât de adânc logos are" (356). 
În schimb, exemplu clar de Catafatism (avant la letter) ni-1 oferă Parmenide (reluat ulterior de Heidegger) prin celebrele spuse:

„Ei bine, voi spune aşadar: tu ia însă aminte la cuvântul pe care-l auzi (despre aceasta):

Care sunt singurele căi ce pot fi luate în seamă pentru o interogare.

Una: cum este ea (ce este ea, fiinţa) şi cum imposibilă (este), de asemenea, nefiinţa.

Aceasta este cărarea încrederii întemeiate, căci ea urmează stării de neascundere.

Cealaltă însă: cum nu este şi totodată cât de nenecesară nefiinţa.

Aceasta deci, astfel vestesc, este o potecă ce nu trebuie urmată defel, căci nu poţi cultiva cunoaşterea nefiinţei, deoarece nu poate fi prinsă nicicum şi nici nu o poţi indica în cuvinte" (Heidegger, 1999: 233).

Trecând de presocratici ajungem la Aristotel în contextul în care, discutând într-un mod apofatic, invers de cel înţeles de obicei despre „potenţă” şi ,act” (în care potenţa este premergătoare actului), el arată că în privinţa „logosului” heraclitean ,aceleaşi lucruri au existat veşnic, fie periodic, fie altfel, pentru că aici actul este anterior potenţei" (Aristotel, 1996: 473); şi afirmă apoi că acest logos este susţinut de o substanţă imaterială, veşnică „,̂n act”2. Iar despre o asemenea substanţă, care se revarsă fără încetare, el spune, tot în mod apofatic, că reprezintă Inteligenţa sau Gândirea Divină (486), dar aceasta nu se confundă cu „Mişcătorul Nemişcat” care o produce.

Mai departe, urmărind evoluţia Catafaticului şi Apofaticului, trecem prin Evul Mediu unde Catafaticul este reprezentat de influenţa arabă (Ibn Arabi, 2017) şi (Rumi, 2016), şi de Toma d'Aquino (doctor angelicus) împreună cu Meister Erckhart, iar pe linie apofatică de Pseudo-Dionisie Aeropagitul (având în spate o întreagă tradiţie patristică ortodoxă), ca să ajună în Europa, în ortodoxism, în anul 586 (a se vedea [Sfântul Dionisie (Pseudo Dionisie) Aeropagitul (1996)] şi apoi în vestul Europei, în catolicism. În continuare, perpetuându-se peste veacuri până în zilele noastre se ajunge la un Apofatic corelat cu Catafaticul, cu scopul final de a atinge Apofaticul pur. Şi acest lucru se întâmplă, în dogmatica ortodoxă, la Lossky (Lossky, 2010), Andre Scrima (Scrima, 2005) şi Dumitru Stăniloaie

\footnotetext{
2 Spre deosebire de receptacolul platonician întotdeauna „potenţial” din Timaios (Platon 1993: 165-166) unde referindu-se la acest „receptacol”, el îl determină în mod negativ (apofatic) deoarece receptacolul nu este nici foc, nici aer, nici pământ, adică este diferit de orice alt element ce ar putea fi considerat primordial. Caracterul non-figurativ al receptacolului îl face incognoscibil în mod pozitiv. Ca în altă parte, în dialogul Parmenide (Platon 1989: 103), să spună: „Unul nu poate fi mai tânăr, mai vârstnic sau acelaşi în vârstă cu sine ori cu altul".
} 
(Stăniloaie, 1996). Mai menţionăm că tot în zilele noastre, având la bază varianta vestică a lucrării pseudo-dionisiace, apare o incitantă comparaţie a apofaticului cu Zenul budist (Kendal, 1983). Această evoluţie care este extrem de interesantă, ba chiar pasionantă, depăşeşte însă net cadrul discuţiei noastre.

În finalul acestei scurte treceri în revistă a doctrinei Apofatic-Catafatică din contextul nostru cultural şi reamintind scopul pe care 1-am urmărit, adică de a şti şi înţelege, de ce există lumea noastră „,naturală” şi „,fizică”, vom putea spune că doar Aristotel in nuce şi varianta dogmatică actuală a creştinismului ortodox, in extenso, par a accepta că apofaticul este primordial în ceea ce priveşte cunoaşterea umană. Şi aceasta deoarece Logosul (în sens heraclitean şi aristotelic) este el însuşi primordial, mai adânc decât Fiinţa. Iar a fi „primordial” în raport cu Fiinţa, din punct de vedere ontologic - există aici o implicaţie ontologică $\breve{a}^{3}$ - presupune că aceasta este condiţionată de acest „logos” nu ca apariţii succesiv în timp, timpul însemnând aici cu totul altceva, ci ca primordialitate.

\section{(xii) Este fenomenologia lui Husserl apofatică sau catafatică?}

Din prezentarea fenomenologiei husserliene rezultă că abordarea sa este eminamente de tip catafatic. Sugestiv, un asemenea tip este pus în evidenţă, în Evul Mediu, de către Ibn Arabi, aşa cum s-a arătat, când afirmă că Fiinţa este primordială, eludând Logosul heracliteano-aristotelic (Ibn Arabi, 2017: 54): "Astfel este, de exemplu, relaţia care leagă cunoaşterea de cel care cunoaşte sau viaţa de cel viu: cunoaşterea şi viaţa sunt realităţi, distincte una de cealaltă; or noi afirmăm, vorbind despre Dumnezeu, că El este cunoscător şi viu [...] şi spunem tot aşa şi despre om."

\section{(xiii) Cea mai importantă incongruenţă husserliană reală: ordinea din Natural.}

Există o „Notă”, plasată între paragrafele 51 şi 52 (Husserl, 2011: 191192), care ne atrage atenţia. În această notă Husserl observă că în Natural, în factic, poate fi intuită o „ordine”. O asemenea ordine ar presupune ceva de natura unei teleologii. Adică a unei desfăşurări a lucrurilor în acord cu lanţul cauzal aristotelic care urmăreşte atingerea unui scop (telos) care ar trebui să rămână neschimbat în esenţă: (a) cauză formală (e.g. arhitectul/ artistul care

\footnotetext{
${ }^{3} \mathrm{Nu}$ trebuie confundată implicaţia logică cu implicaţia cauzală pentru că, deşi se citesc la fel, cele două înseamnă lucruri foarte diferite. Implicaţia cauzală nu este o relaţie logica, ci una ontologica, ea inseamna: "ori de cate ori se produce $P$, se produce $Q$ " sau "daca are loc $P$ (cauza), are loc $Q$ (efectul)". Implicatia logică este altceva, ea inseamna: "adevarul lui $P$ implica adevarul lui $Q$ " sau "daca este adevarat $P$, atunci este adevarat $Q$ ". Am putea spune, eventual, ca adevarul lui $P$ este cauza pentru adevarul lui $Q$. În acest caz, implicatia logică devine un caz particular al implicatiei cauzale.
} 
propune proiectul unei case/ opere de artă), (b) cauză materială (e.g. materialul de construcţie), (c) cauză eficientă (e.g. constructorul/ realizatorul) şi (d) cauză finală (e.g. realizarea casei/ operei de artă) ${ }^{4}$. Ori o astfel de teleologie pune în evidenţă schimbările care se petrec la nivelul Naturalului. Întrebările care apar: Cine şi Unde fixează scopul? şi Care este scopul (în esenţă)?

Pentru a merge mai departe, este nevoie de o paranteză. Trebuie menţionat, în mod deosebit, ca Husserl nu are în vedere o cauzalitate de tip galileo-newtonian, cantitativă şi anume de relaţii între părţi ale realităţii realität de tip „,cauză-efect” fără scop: „este evident că 'exercitarea' acestui principiu nu ar putea fi concepută în termeni cauzali, aşadar în sensul conceptului natural de cauzalitate". A se vedea, în acest sens (Patočka, 2017: 17): "În timp ce pentru Galilei mişcarea are un caracter de quantum [...] care ţine de sfera relatiilor, pentru Aristotel mişcarea este în mod principial necantitativă. [...] Doar un nivel ontologic mai profund [...] ne permite să înţelegem în mod fundamental mişcarea". Am închis paranteza.

Dacă scopul ar fi fixat la nivelul Naturalului de către o Divinitate mundană, atunci se ajunge la o circularitate. Căci aceasta ar însemna că o asemenea Divinitate s-ar afla, ea însăşi, în acest nivel. Ori în acest caz, la fiecare schimbare, s-ar produce şi schimbarea scopului deoarece chiar şi Divinitatea, care face parte din Natural, s-ar schimba. Şi Husserl ia în calcul aceasta.

Dacă scopul ar fi fixat la nivelul Transcendentalului de către Fiinţa absolută, nici acest lucru nu ar fi posibil deoarece această fiinţă are un scop bine definit. Şi anume, conform doctrinei „constituirii”, de a oferi „existenţă” (fiinţare). S-ar putea obiecta că fiinţarea nu presupune ,îngheţarea” scopului în cadrul schimbărilor care se petrec în Natural în cadrul chiar al „fiinţării”. Dar atunci acesta nu ar mai rămâne neschimbat în esenţă.

Soluţia pe care o întrevede Husserl este ca fixarea scopului să se realizeze în Absolut: ,principiul ordonator (scopul) [...] trebuie găsit la nivelul absolutului însuşi, şi anume prin intermediul unor considerente pur absolute” (191). Însă, deoarece ,imanenţa lui Dumnezeu în cadrul Conştiinţei absolute (pure) nu poate fi concepută [Dumnezeu/ Absolutul a fost redus fenomenologic din start G.M.]” atunci ,ar trebui să se găsească diverse [alte] forme intuitive de relevare" (192). Lucru pe care Husserl nu îl face.

Comentariul 10.Considerăm că în comparaţie cu perspectiva deschisă de , apofatic-catafatic”, demersul husserlian apare drept unul reducţionist.

\footnotetext{
${ }^{4}$ Această teleologie este exploatată, din punct de vedere fenomenologic, de (Patočka 2017: 17-33).
} 
Astfel, nu ne opreşte nimeni să considerăm că acest principiu/ scop nu se află în Absolutul pe care Husserl l-a redus fenomenologic, ci la nivelul „logosului heracliteano-aristotelic" de natură apofatică. În măsura în care s-ar depăşi această perspectivă reducţionistă, discursul fenomenologic ar putea căpăta o altă turnură aşa cum se va vedea în abordarea lui Mihai Drăgănescu, într-un text viitor.

\section{(xiv) Concluzii}

În acest text, aşa cum s-a specificat, s-a urmărit identificarea unor probleme pe care le deschide fenomenologia lui Husserl prin prisma integrării sale în Modelul ontologic informaţional propus de Mihai Drăgănescu. Iată care sunt, după noi, cele mai importante.

(i) Considerăm că Husserl ia în considerare numai aspectul catafatic al cunoaşterii şi acţiunii umane. (Comentariul 10).

(ii) Considerăm că principiul/ scopul ordinii din Natural se află la nivelul „logosului heracliteano-aristotelic” din cadrul demersului apofatic. (Comentariul 10).

(iii) S-a pus în evidenţă faptul că, în timp ce Naturalul este găzduit de un topos cu extindere în trei dimensiuni şi durată în timp, lucrurile de aici având un suport material, în schimb despre Transcendental Husserl nu afirmă nimic în legătură cu spaţialitatea, timpul şi „susţinerea” lucrurilor de aici. (Comentariul 1)

(iv) Extinderea intuiţiei dincolo de empirism şi postularea posibilităţii ca prin ea cunoaşterea umană să aibă acces la Transcendental precum şi declararea acestuia drept ,real'” sunt, cel puţin discutabile, în măsura în care Transcendentalul este considerat ca fiind cantonat într-un areal al unui „niciunde” şi „nici când” fără susţinere de nici un fel. (Comentariul 2 şi Comentariul 3).

(v) În legătură cu Ontologia formală (propusă de Husserl) apare o întrebare la care nu se răspunde. Şi anume, dacă formalul se află în Transcendental sau nu? (Comentariul 5).

(vi) Pot exista şi lanţuri de ,incluziuni”. Cum le numeşte Husserl, care să cuprindă trăiri multiple, în cadrul cărora fiecare trăire superioară nu este autonomă ci fondată pe una inferioară, printr-o regresie la infinit? Husserl nu spune nimic despre aceasta (Comentariul 7).

(vii) Paradoxul lui Lyotard (Comentariul 9) poate fi înlăturat dacă se admite ipoteza noastră conform căreia Conştiinţa pură îşi ia drept partener omul la „,constituirea” lumii naturale şi a celei formale (Comentariul 8). 


\section{Referințe:}

Arabi, I. (2017). Cartea înţelepciunii/ Book of Wisdom. Bucureşti: Herald.

Aristotel (1996). Metafizica/ Metaphysics. Bucureşti: Iri.

Bauman, U. (1998). Kausalität and qualitative empirische Sozialforschung/ Causality and qualitative empirical social research. New York, Munchen, Berlin: Waxmann Münster.

Cogan, J. (2006). The Phenomenological Reduction. Retrieved 1 Feb. 2019. from https: / / www.iep.utm.edu/ phen-red/.

Ciocan, C. (2007). Critica lui Heidegger la adresa lui Husserl/ Heidegger's criticism against Husserl. În Ciocan, C. \& Lazea, D. (Ed.), Intenţionalitatea de la Plotin la Levinas (pp. 161-180). Bucureşti: Zeta books.

Dermot, M. (2012). The Husserl Dictionary. Dublin: University College Dublin.

Drăgănescu, M. (1985). Ortofizica/ Orthophysics. Bucureşti: Editura Ştiinţifică şi Enciclopedică.

Drăgănescu, M. (1979). Profunzimile lumii materiale/ The Depths of Existence. Bucureşti: Editura Politică.

Drăgănescu, M. (2007). Societatea Conştiinţei/ Consciousness society. Bucureşti: Institutul de Inteligenţă Artificială al Academiei Române.

Drummond, J. (2007). Historical Dictionary of Husserl's Philosophy. Scarecrow Press.

Dumitriu, A. (1969). Istoria logicii/ History of Logic. Bucureşti: Editura Didactică şi Pedagogică.

Fărcaş, D. (2010). Meister Erckhart/ Meister Erckhart. Bucureşti: Polirom.

Graham, P. (2002). Beyond the Limits of thought. Oxford University Press.

Heidegger, M. (2003). Fiinţă şi timp/ Being and Time. Bucureşti: Humanitas.

Heidegger, M. (1999). Introducere în metafizică/ Introduction to Metaphysics. Bucureşti: Humanitas.

Henning, B. (2006). What is Formal Ontology?, Metaphysics 1, 2- 21.

Husserl, E. (1994a). Filosofia ca ştiinţă riguroasă/ Philosophy as rigorous science. Bucureşti: Paideia.

Husserl, E. (1994b). Meditaţii Cartezienel Cartesian meditations. Bucureşti: Humanitas.

Husserl, E. (2011). Idei privitoare la o fenomenologie pură şi la o filozofie fenomenologică. Cartea întâi (I) [Idei I]: Introducere general în fenomenologia pură/ Ideas Pertaining to a Pure Phenomenology and to a Phenomenological Philosophy - First Book: General Introduction to a Pure Phenomenology,. Bucureşti: Humanitas.

Husserl, E. (2012). Cercetări logice II/ Logical Investigations II. Bucureşti: Humanitas.

Kaku, M. (2016). Viitorul minţii umane/ The Future of the Mind. Bucureşti: Trei.

Kant, I. (1969). Critica raţiunii pure/ Critique of Pure Reason. Bucureşti: Editura Ştiinţifică.

Kendal, J. (1983). Through Words and Silence: A Comparative Study of William Johston and Thomas Merton, Roman Catholics in Dialogue with Zen. The University of British Columbia. 
Locke, J. (1961). Eseu asupra intelectului omenesc/ An Essay Concerning Human Understanding . Bucureşti: Editura Ştiinţ̧ifică şi Enciclopedică.

Lossky, V. (2010). Teologia mistică a bisericii de răsărit/ Mystical Theology of the Eastern Church, București: Humanitas.

Lyotard, J. (1954), La Phénoménologiel The Phenomenology. Paris, Presses universitaires de France.

Manolescu, G. (2013). Fenomenologicul la Mihai Drăgănescu: conştiinţa fundamentală a existenţei/ Phenomenology of Mihai Draganescu and Foundamental Consciousness. In Noema. XII. 13-29.

Manolescu, G. (2014). Drăgănescu şi sensul fenomenologic/ Draganescu and the phenomenological sense. In Noema, XIII. 19-28.

Manolescu, G. (2015). Mihai Drăgănescu - Noua paradigmă a informaţiei/ Mihai Drăgănescu - new paradigm of information. In Academica, XXV(6-7). 38-42.

Manolescu, G. (2017). Mihai Drăgănescu, o prioritate românească: cosmologia informaţională versus universul holografic/ Mihai Drăgănescu, a Romanian priority: Informational Cosmology versus Holographic Universe. In Noema,XVI. 11-32.

Manolescu, G. (2018), Despre tetra-lemă. Insemnări fragmentare şi fugare/ About Tetra-lemma. Fragmentary, fleeting notes. In NOEMA, XVII. 131-140.

Piatkovski A. \& Banu, I. (1979). Filosofia greacă până la Platon Vol. I, Partea a 2 a/ Greek philosophy before Plato Vol. I, Part Two. Bucureşti: Editura Ştiinţifică şi Enciclopedică.

Platon (1993). Opere VII, Timaios/ Timaeus . Bucureşti: Editura Ştiinţifică.

Platon (1989). Opere VI, Parmenide/ Parmenides. Bucureşti: Editura Ştiinţifică.

Patočka, J. (2017). Mişcare, lume, tehnică. Studii fenomenologicel Motion, world, technique. Phenomenological studies. Cluj: Tact.

Rumi (2016). Oceanul sufletului/ The ocean of soul. , Bucureşti: Herald.

Sfântul Dionisie (Pseudo Dionisie) Aeropagitul (1996). Opere complete/ Complete works . Bucureşti: Paideia.

Schmitz H., (forthcoming), Scurtă introducere în noua fenomenologiel Brief introduction to the new phenomenology. Oradea: Ratio et Revelatio [prezentat în primăvara anului 2019 în cadrul Seminarului „Noua fenomenologie” susţinut de Cristian Ferencz-Flatz la ICUB Humanities].

Scrima, A. (2005). Antropologia apofatică/ Apophatic anthropology. Bucureşti. Humanitas.

Stăniloaie, D. (1996). Teologia dogmatică ortodoxă, vol. I/ Orthodox Dogmatic Theology, vol. 1. Bucureşti: Editura Institutului biblic de misiune al Bisericii ortodoxe române.

Surdu, A. (1995). Vocaţii filosofice româneşti/ Romanian philosophical vocation. Bucureşti: Editura Academiei.

Zahavi, D. (2017). Fenomenologia lui Husserl/ Husserl's phenomenology. Oradea: Ratio et Revelatio. 